\title{
Intestinal dissaccharidase activity after Billroth II resection for peptic ulcer
}

\author{
E. GUDMAND-HØYER, S. JARNUM, AND H. WORNING \\ From Medical Department P, the Division of Gastroenterology, and Surgical Department C, \\ Gastroenterological Unit, Rigshospitalet, Copenhagen, Denmark
}

The simultaneous investigation of disaccharide tolerance and the concentrations of disaccharidases in the intestinal epithelium in patients subjected to subtotal gastrectomy is unusual. The incidence of lactase deficiency in such patients has been studied by Kojecký and Matlocha (1965), by Welsh, Shaw, and Walker (1966), and by Drube, Hansen, Klein, and Zielke (1967). The results obtained were highly divergent. Kojecký and Matlocha observed decreased concentration of lactase in $42 \%$ of the 24 patients studied whereas Drube et al made a similar observation in one out of 20 patients.

Systematic studies of the concentration of disaccharidases as a function of the distance from the gastrojejunal stoma are lacking. In the present paper, the distribution of disaccharidases and alkaline phosphatase in the proximal $50 \mathrm{~cm}$ of the efferent loop in patients subjected to subtotal gastrectomy with gastrojejunostomy (Billroth II resection) has been studied.

\section{MATERIAL AND METHODS}

Thirteen patients, six females and seven males, were studied. They had all been subjected to subtotal gastrectomy with gastrojejunostomy two to 27 years before the present investigation.

In all patients tolerance tests for lactose, sucrose, and maltose were performed as described earlier (Gudmand-Høyer and Jarnum, 1968). Small intestinal biopsies were taken by Rubin's hydraulic multibiopsy suction tube $50,30,20,10$, and $5 \mathrm{~cm}$ distally to the gastrojejunal stoma. The biopsies were placed in sealed tubes on ice and deep frozen $\left(-25^{\circ} \mathrm{C}\right)$ within an hour. In all biopsies the concentrations of protein, of alkaline phosphatase, and of disaccharidases (lactase, sucrase, and maltase) were estimated within a week after the biopsies were taken. Supplementary biopsies for histological examination were taken 50,20 , and $5 \mathrm{~cm}$ distally to the stoma.

Concentration of protein was estimated in accordance with the method of Lowry, Rosebrough, Farr, and Randall (1951), alkaline phosphatase by the method of Bessey, Lowry, and Brock (1946), and disaccharidases by the one-step method of Messer and Dahlqvist (1966). Concentrations of enzymes are given in international units per gram of protein.

The comparison of concentration values at different distances from the stoma are based on the differences between the concentrations at the two distances in question. The means of these differences were examined for significant difference from zero by Student's test.

RESULTS

The histological appearance was normal in all biopsies. No signs of villous atrophy or inflammatory reaction were observed in any biopsy.

The disaccharide tolerance tests were normal in all patients.

The observed concentrations of the different enzymes as a function of the distance from the stoma are presented in Figures 1 to 4 . The figures also contain the mean value for each enzyme.

As a general rule, the concentrations of the different enzymes were lowest close to the stoma. They increased in the following $15 \mathrm{~cm}$ and remained at a constant level in the region 20 to $50 \mathrm{~cm}$ from the stoma (Figs. 1 to 4 ).

Table I shows the P values for the differences between concentrations at different distances from the stoma. The increase in concentration was significant in the region 5 to $10 \mathrm{~cm}$ and 10 to $20 \mathrm{~cm}$ for maltase and alkaline phosphatase, respectively.

Concentrations of all enzymes were within normal limits in all biopsies taken 20,30 , and $50 \mathrm{~cm}$ distally to the stoma. In six patients decreased concentrations of one or more enzymes were observed in the biopsies taken 5 or $10 \mathrm{~cm}$ distally to the stoma. Table II shows the incidence of decreased concentrations in these six patients. Lactase concentration was below the normal value in five, sucrase and alkaline phosphatase in three patients each, and maltase in one patient. Four patients presented decreased concentrations of more than one enzyme (Table II). 


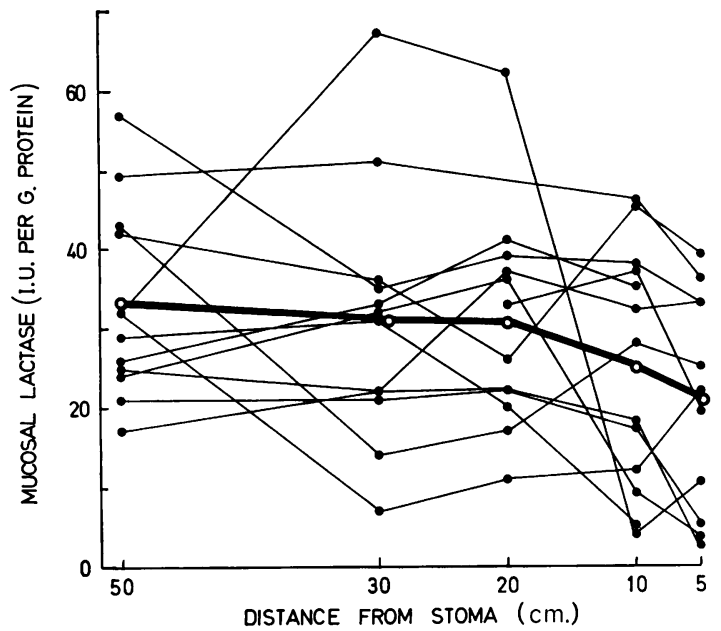

FIG. 1. Small intestinal mucosal lactase at various distances from the gastrojejunostomy in 13 patients subjected to Billroth II resection. The heavy line indicates mean values.

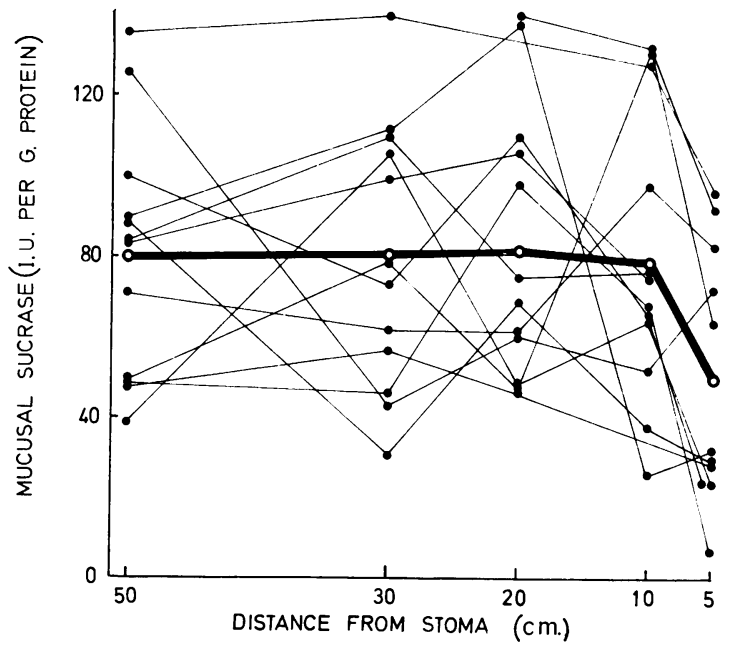

FIG. 2. Mucosal sucrase in gastrectomized patients.

\section{DISCUSSION}

The observed systematic increase in the concentrations of disaccharidases in the first $20 \mathrm{~cm}$ distally to the gastrojejunal stoma is not a result of normal variation. In the actual region of the small intestine, the concentrations of enzymes are fairly constant (Newcomer and McGill, 1966).

The controversial data concerning the incidence of lactase deficiency in patients subjected to subtotal gastrectomy (Kojecký and Matlocha, 1965;

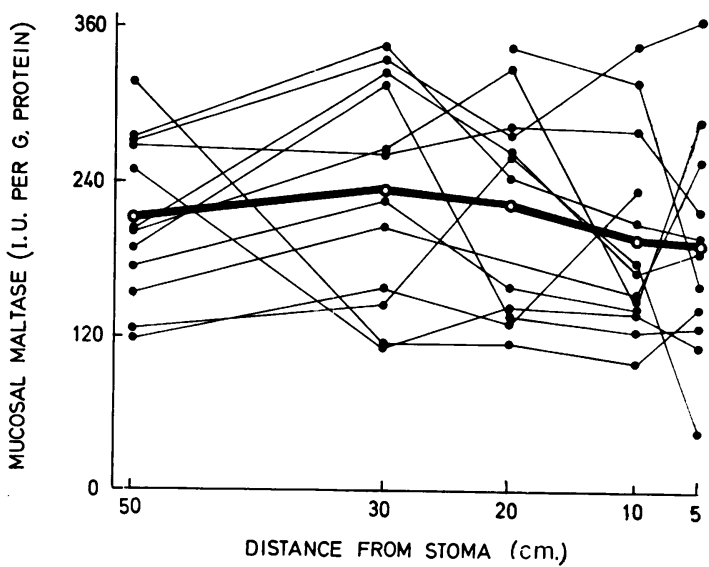

FIG. 3. Mucosal maltase in gastrectomized patients.

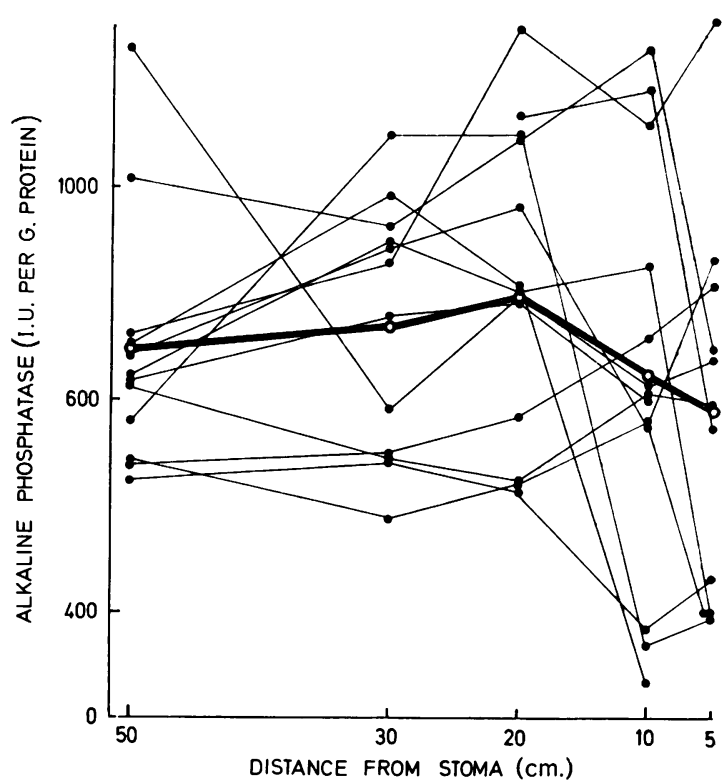

FIG. 4. Mucosal alkaline phosphatase in gastrectomized patients.

Welsh et al, 1966; Drube et al, 1967) are not dependent on racial differences as all studies were performed in Caucasians. It seems more probable to ascribe the differences to the observed systematic variation in concentrations of enzymes in the first $20 \mathrm{~cm}$ of the efferent loop. Thus, Kojecký and Matlocha (1965), who reported lactase deficiency in $42 \%$ of the patients, obtained their biopsies 10 to $15 \mathrm{~cm}$ distally to the stoma, whereas Drube et al (1967) in biopsies taken 20 to $40 \mathrm{~cm}$ distally to the stoma only observed decreased jejunal lactase activity in one patient. 
TABLE I

VALUES FOR P FOR DIFFERENCES IN CONCENTRATIONS AT DIFFERENT DISTANCES FROM THE GASTROJEJUNAL STOMA

Enzyme Distance from Stoma $(\mathrm{cm})$

\begin{tabular}{|c|c|c|c|c|c|}
\hline & & & & & \\
\hline & $50-5$ & $50-10$ & $20-5$ & $20-10$ & $10-5$ \\
\hline Lactase & $\begin{array}{l}0.005>p \\
>0.0025\end{array}$ & $\begin{array}{l}0.025>p \\
>0.0125\end{array}$ & & & $\begin{array}{l}0.05>p \\
>0.025\end{array}$ \\
\hline Sucrase & $\begin{array}{l}0.0125>p \\
>0.01\end{array}$ & & $\begin{array}{l}0.05>p \\
>0.025\end{array}$ & & $\begin{array}{l}0.005>p \\
>0.0025\end{array}$ \\
\hline Maltase & & & $\begin{array}{l}0.05>p \\
>0.025\end{array}$ & & \\
\hline $\begin{array}{l}\text { Alkaline } \\
\text { phosphatase }\end{array}$ & & & & $\begin{array}{l}0.05>p \\
>0.025\end{array}$ & \\
\hline $\mathbf{n}$ & 10 & 12 & 10 & 12 & 11 \\
\hline
\end{tabular}

TABLE II

PATIENTS WITH DECREASED JEJUNAL ENZYME ACTIVITY 5 CM AND/OR 10 CM FROM THE STOMA

\begin{tabular}{lllll} 
Patient & Lactase & Sucrase & Maltase & $\begin{array}{l}\text { Alkaline } \\
\text { Phosphatase }\end{array}$ \\
\hline 1 & + & & & + \\
2 & + & + & + & + \\
3 & + & & & + \\
4 & + & + & & \\
5 & + & + & & 3 \\
6 & 5 & 3 & 1 &
\end{tabular}

The common existence of multiple enzyme deficiency in the first centimetres distally to the stoma (Table II) indicates that the phenomenon most probably is unspecific. The higher incidence of deficiency of lactase compared with that of the other enzymes is in fair accord with the results of Haemmerli, Kistler, Ammann, Marthaler, and Semenza (1965), Littman and Hammond (1965), and Larrechea, Sampayo, and Miatello (1965), who claimed lactase as the enzyme most susceptible to damage.

None of the patients investigated here presented evidence of disaccharide intolerance. Thus the low concentrations of disaccharidases in the first centimetres distally to the stoma were of no consequence for disaccharide absorption.

The reason for the common existence of low concentrations of enzymes in the first part of the intestine distally to the gastrojejunostomy stoma remains unknown. The histological examinations did not support the existence of nutritive defects or inflammatory reaction in the efferent loop.

The conclusion to be drawn is that biopsies taken in the first $20 \mathrm{~cm}$ distally to a gastrojejunal stoma are of no significance for the diagnosis of disaccharide malabsorption in patients with Billroth II resections.

\section{SUMMARY}

Disaccharide tolerance tests as well as concentrations of disaccharidases in multiple biopsies from the first $50 \mathrm{~cm}$ of the efferent loop were performed in 13 patients with a gastrojejunostomy following subtotal gastrectomy. None of the patients presented signs of disaccharide intolerance. Concentrations of disaccharidases varied systematically in the efferent loop; the lowest concentrations were observed near the stoma. In the following $20 \mathrm{~cm}$ the concentration increased to remain constant in the rest of the intestine studied. In six patients concentrations of enzymes below the lowest normal value were observed in the biopsies near the stoma. The histological picture of the biopsies was normal, even in those presenting low concentrations of enzymes. The existence of low concentrations of enzymes in the first $20 \mathrm{~cm}$ of the efferent loop is of no significance for the diagnosis of disaccharide malabsorption.

\section{REFERENCES}

Bessey, O. A., Lowry, O. H., and Brock, M. J. (1946). A method for the rapid determination of alkaline phosphatase with five cubic millimeters of serum. J. biol. Chem., 164, 321-329.

Drube, H. C., Hansen, H. T., Klein, U. E., and Zielke, K. (1967). Úber die Disaccharidasen-aktivität der Jejunalschleimhaut bei Gesunden und Magenresezierten. Dtsch. med. Wschr., 92, 960-963.

Gudmand-Høyer, E., and Jarnum, S. (1968). The diagnosis of lactose malabsorption. Scand. J. Gastroent., 3, 129-139.

Haemmerli, U. P., Kistler, H., Ammann, R., Marthaler, T., Semenza, G., Auricchio, S., and Prader, A. (1965). Acquired milk intolerance in the adult caused by lactose malabsorption due to a selective deficiency of intestinal lactase activity. Amer. J. Med., 38, 7-30.

Kojecký, Z., and Matlocha, Z. (1965). Quantitative differences of intestinal disaccharidase activity following the resection of stomach. Gastroenterologia (Basel), 104, 343-351.

Larrechea, I. de, Sampayo, R. R. L., and Miatello, C. S. (1965). Disaccharidase deficiency in non-tropical sprue, Whipplés disease and congenital intestinal lymphangiectasia. Abstn. Gastroenterology, 48, 829-830.

Littman, A., and Hammond, J. B. (1965). Diarrhoea in adults caused by deficiency in intestinal disaccharidases. Ibid., 48, 237-249.

Lowry, O. H., Rosebrough, N. J., Farr, A. L., and Randall, R. J. (1951). Protein measurement with the Folin phenol reagent. J. biol. Chem., 193, 265-275.

Messer, M., and Dahlqvist, A. (1966). A one-step ultra-micro method for the assay of intestinal disaccharidases. Analyt. Biochem., 14, 376-392.

Newcomer, A. D., and McGill, D. B. (1966). Distribution of disaccharidase activity in the small bowel of normal and lactasedeficient subjects. Gastroenterology, 51, 481-488.

Welsh, J. D., Shaw, R. W., and Walker, A. (1966). Isolated lactase deficiency producing postgastrectomy milk intolerance. Ann. intern. Med., 64, 1252-1258. 